One of the most accessible methods of mock-up in the educational process is paper plastics, in the technique of which students create a design-search paper layout, in which the means of formation convey a plastic solution to the shape of clothing. Origami texture has moved from paper plastics to fashion design, the characteristic features of which are emphasized and exaggerated form stability of materials (origami in clothing has varieties-modular origami and kirigami).

Mock-up making in the study of artistic design of clothing is solved by the methods of spatial modeling on a mannequin or on a human figure by the methods of modeling and sketch impaling, which serve as a platform for experiments in the formation of a suit, provide an opportunity for operational evaluation of work in the process of development and modeling.

Textural shaping is an effective means of expression of both the surface of the textile fabric and the shape of the product; the study of the possibilities of using this method in the classroom technology expands the range of vocational training of young people and encourages future teachers of technology to further experiments.

Keywords: technology classes in high school; artistic design of clothes; methods of shaping clothes; mock-up making; texture shaping; paper plastics

Стаття надійшла до редакції 15.09.2019 р.

УдК 37.091.4Гордієнко

DOI: https://doi.org/10.33989/2075-146x.2019.24.194867

\title{
НИНА ПИВОВАР
}

ORCID ID 0000-0002-7047-782X

\section{ОЛЕНА КРИВОНОС}

Полтавський національний педагогічний університет імені В.Г. Короленка

\section{МИХАЙЛО ГОРДІЄНКО - ЗАНОВО ВІДКРИТА ПОСТАТЬ У ВІТЧИЗНЯНІЙ ПЕДАГОГІЦІ}

\begin{abstract}
Стаття написана в контексті актуального нині пошуку, вивчення й оприлюднення передового педагогічного досвіду маловідомих вчителів, майстрів педагогічної праці, який би послугував у розв'язанні аналогічних проблем виховання дітей-сиріт, але у зовсім нових соціально-економічних умовах. Присвячена педагогічному спадку Михайла Гордієнка - директора Охтирського спеціального дитячого будинку №1 для сиріт загиблих фронтовиків та партизанів.
\end{abstract}

Ключові слова: педагогічний спадок; Михайло Гордієнко; діти-сироти; безпритульність; спеціальний дитячий будинок; управління; трудове виховання

Постановка проблеми. Сирітство - одна 3 проблем, яка супроводжує людське суспільство на всіх етапах його розвитку. Залишається актуальною вона і в сучасній Україні, де, за статистикою, «станом на 31 грудня 2018 року ... на обліку дітей-сиріт та дітей, позбавлених батьківського піклування, перебувала 70491 дитина. Із них 22126 дітейсиріт та 48365 дітей, позбавлених батьківського піклування» (Скільки дітей..., 2019). Вирішується згадана проблема на різних рівнях - на державному, соціальному, педагогічному, з залученням досвіду передових країн світу. Проте й у вітчизняній практиці зустрічаємо приклади педагогічного подвижництва, гідні того, аби бути згаданими при вирішенні завдань виховного впливу на дітей, які з різних причин були позбавлені рідної сім’ї.

Саме тому автори вважають важливим оприлюднити інформацію про не відомого широкому загалу, але глибоко шанованого всіма, хто був свідком його талановитої й результативної роботи з дітьми-сиротами, педагогавихователя, менеджера Михайла Андрійовича Гордієнка (1910-1960).

Аналіз досліджень і публікацій. М. А. Гордієнко був одним із «рядових» педагогів свого часу, що, на перший погляд, мало чим вирізнявся на тлі вітчизняної педагогічної спільноти, так само, як і очолюваний ним дитячий будинок не зажив широкої слави серед собі подібних. I хоча ця людина, подібно до багатьох самовідданих майстрів педагогічної справи, залишила непересічний слід у долях десятків своїх вихованців, достатньо інформативних та аналітичних публікацій про М. Гордієнка не існує, за винятком документальної повісті-есе Лесі Криницької «Дочки і синочки, або Життя за Піфагором: «Бережіть сльози своїх дітей, аби вони могли плакати на Вашій могилі!» (Історія дитячого будинку - історія самої Охтирки), яка нещодавно опублікована Харківським видавництвом «Факт» і більшою мірою носить публіцистичний характер.

Мета статті: дослідити сутність та особливості роботи М А. Гордієнка 3 педагогічних позицій, на предмет використання елементів його досвіду у роботі з дітьми- сиротами в сучасних умовах.

Виклад основного матеріалу.

Упродовж трьох останніх десятиліть новітньої історії України науковці здійснюють активні пошуки соціальнопозитивних та продуктивних педагогів, що в різні часи стали найзначущішими людьми в житті своїх вихованців. Поки що їхні образи в більшості губляться на тлі широко відомих педагогів світу XX століття (Януша Корчака, Антона Макаренка, Василя Сухомлинського та інших, хто давно ввійшов до когорти класиків педагогіки). Але поступово, завдяки пошуку вчених, краєзнавців, ентузіастів, вони постають реальними людьми, талановитими трудівниками, котрі зробили свій потужний внесок до скарбниці педагогічної науки і практики. 
Цей процес сьогодні активізується і актуалізується (Кривич, 2016; Штань, 2017 та ін.), і насамперед, тому, що, як відзначають дослідники, нині, як і у 20-х роках ХХ століття «в Україні склалася надзвичайно складна політична й соціально-економічна ситуація, що негативно позначилася на становищі освітніх закладів, поповнила армії безпритульних і бездоглядних дітей. Подібну ситуацію українське суспільство переживає і сьогодні... Крім того, у світі надзвичайно гострою залишається проблема безпритульних дітей і дітей-сиріт: безробіття, воєнні конфлікти, епідемії зумовлюють їх появу», - зазначає дослідниця історії функціонування дитячих будинків на Сумщині О. Кривич. Невичерпною скарбницею цінних думок, ідей, починань та висновків називає вона досвід минулого і наголошує, що «аналіз досягнень і недоліків подолання безпритульності у 20-х роках XX століття допоможе уникнути помилок у розв'язанні цієї проблеми і сприятиме створенню наукових підходів щодо практики виховання даного контингенту дітей» (Кривич, 2016, с. 96-96).

Тож важливою, непересічною педагогічною постаттю сьогодні постає М. А. Гордієнко - колишній директор закладу, що носив назву «Охтирський спеціальний дитячий будинок №1 для сиріт загиблих у Великій Вітчизняній війні фронтовиків та партизанів».

Біографічні дані педагога поновлюємо насамперед за рукописом спогадів його доньки Н. М. Гордієнко, що зберігаються в особистому архіві Г.П. Гапонової (Хілько). «Михайло Андрійович Гордієнко народився у м. Охтирці 5 листопада 1910 р., - згадує Наталія Михайлівна. - Освіта - вища педагогічна. В Охтирському Дитячому містечку iм. М. О. Скрипника на Монастирській горі (Охтир-горі) був комсомольським організатором у Народній сільськогосподарській школі (НСШ) аж до розформування Дитмістечка у 1939 р. До початку війни працював

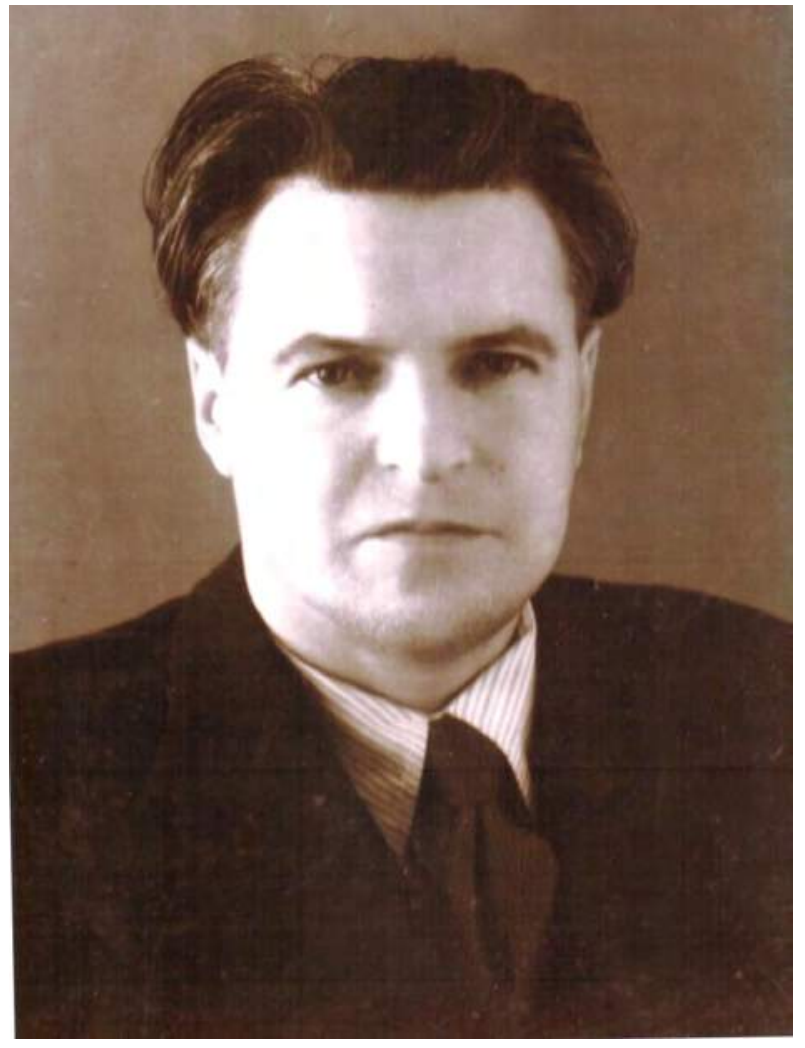

М. А. Гордієнко. Фото 1960-го р.

А діти, з якими працював Гордієнко, були вражені й фізично, й душевно, вочевидь, іще сильніше, аніж діти 20-х, адже довелося жити і сиротіти під час найжорстокішої в історії людства війни, що своїми фронтами-котками двічі прокотилася містечком (восени 1941 року та насамкінець літа 1943-го), виживати під час окупації Охтирки. Багато хто 3 цих неповнолітніх не раз і не двічі побував свідком не лише реальних боїв за місто, але й примусовим свідком публічних страт людей через повішення: партизанів та заложників на центральній площі міста, куди окупанти зганяли, окрім дорослого населення, і дітей з ближніх, працюючих і в окупацію, шкіл...

Що ж є визначальними рисами в педагогічній діяльності М.Гордієнка?

Звичайно, це те, що перш за все Михайло Андрійович застосував, як свого часу це зробив його педагогічний наставник Матвій Лукич Довгополюк у Охтирському Дитмістечку на Охтир-горі (село Доброславівка Охтирського району Сумської області), метод цілком народної педагогіки: виховання та психологічне лікування у праці, щонайтісніший зв'язок із реальним життям, що вирує поза парканом дитячого закладу.

Тож недарма Михайло Андрійович відразу, ставши керівником, започаткував при спецдитбудинку підсобне господарство (у с. Пологи, що знаходиться майже впритул до Охтирки), де постійно працювали не лише наймані працівники, але й вихованці. Діти бачили плоди своєї праці не тільки в кагатах та на свино- і молочнотоварній фермах, але й на столах у спільній на всіх їдальні. Принцип змагальності як дитячих колективів, так і окремих особистостей, став тут дуже важливим поруч із принципом відповідальності одного за всіх, всіх - за одного. Недарма підсобне господарство цього дитбудинку на Всесоюзній виставці народного господарства СРСР у Москві невдовзі отримало медаль учасника. I з такою емблемою на чолі своєї колони дитбудинок з гордістю ходив на всі 
урочисті, святкові демонстрації в Охтирці (інколи і в Сумах, що було своєрідною нагородою за перше місце у змаганнях дитячих будинків області у навчанні та праці, за успіхи в художній самодіяльності).

Роками (а потім і десятиліттями, упродовж усього свого життя) вихованці Гордієнка сприймали, як єдино правильний, саме його, гордієнківський, принцип: «Не виростиш, не заробиш - не з'їси!»

За директорства М. А. Гордієнка у їдальні дитбудинку відразу було встановлено обов'язкове чергування дітей для самообслуговування. Завжди чергували вихованці і в своїх спальнях, а також і в класних, ігрових кімнатах, прибираючи, прикрашаючи їх тощо. Змагальний принцип був обов'язковим і тут. Отож, почуття особистої та колективної відповідальності, вміння будувати нормальні міжособистісні психологічні стосунки росли й міцніли і в цьому посильному трудовому процесі.

Різноманітні гуртки, що привчали до праці, тимурівське шефство, поєднання загального педагогічного керівництва 3 дитячим, учнівським самоуправлінням, ба, навіть самодіяльністю, - це також елементи системи успішної соціалізації дітей-сиріт, які застосовував Гордієнко-директор і як дипломований педагог загалом, і як послідовник М. Л. Довгополюка, а значить - і А. С. Макаренка. Модель рідної сім'ї тут успішно проектувалася на великий дитячо-педагогічний колектив закладу, про який рука не піднімається написати модне нині слово «сиротинець». Тим більше, що за спинами педагогів та технічних працівників, котрі, по суті, ставали справжніми батьками й матерями сиротам війни, височіли ще й дуже міцні постаті шефів. Гордієнко, як і свого часу Макаренко та Довгополюк, зміг зорганізувати на постійну підмогу своїм «дочкам та синочкам» (він завжди виключно так називав своїх підопічних!) Охтирський завод «Промзв'язок» (найкрупніший в СРСР серед 23-х подібних підприємств), місцеву швейну фабрику, завод медичних меблів, інших промисловиків, а також колгосп-мільйонер імені Петровського.

Необхідно підкреслити: ідеї гуманістичного виховання, демократії, самоуправління, котрими свого часу послуговувалися у практичній педагогіці й Макаренко, й Довгополюк, з молодих літ були притаманні й світогляду Гордієнка. Це відобразилося й на результатах діяльності очолюваного ним дитбудинку. Недарма вихователька Анна Павленко, одна 3 відомих у Охтирці майстрів педагогічної праці, згадувала свого часу в пресі: «Якось у мене запитали:

- Який коефіцієнт корисної дії педагогіки у вашому дитдомі?

Я впевнено і з гордістю за своїх випускників відповіла:

- Високий!

І небезпідставно. Судіть самі. Я спиралася у цьому своєму судженні ось на що: багато наших дітей, закінчивши вузи, технікуми, училища, стали висококласними спеціалістами, i, зокрема (що особливо радує!), як і ми, педагогами! Однією з перших стала учителькою Зоя Кан. Багато літ віддали улюбленій педагогіці Ніна Горобець, Рая Галкіна, Галя Головко, Фрося Киясь, Ніна Хащина, Ваня Дацюк, Мишко Жувак, Вася Жила, Паша Андросова, Оля Зосимова, сестри Таня й Маша Пономаренки. Педстаж кожного - десятки років» (Павленко, 1998).

Крім того, абсолютно кожен випускник дитбудинку постійно згадував, а хто іще живий - і досі згадує незвичайну особистість самого Михайла Андрійовича: високогуманну, духовно витончену людину, справді доброго батька для них усіх. Ось фрагмент спогадів Г. П. Гапонової (в дівоцтві Хілько):

«Ще продовжується війна... Іде територією дитбудинку комісований фронтовик, герой Сталінграду, - наш директор, Михайло Андрійович. Йде, як завжди, у військовій формі. Назустріч йому - хлопчина. Директор обов'язково його зупинить:

- Синку! Підійди-но сюди. Скажи: тебе ніхто не зобиджає? Ти не голодний?! Наїдаєшся? Добре. Ну, йди собі.

Побачить дівчинку:

- Дочечка! Тебе ніхто не зобиджає?! Не голодна? Добре... Біжи собі далі.

Ми доводилися йому не просто дітьми-вихованцями: кожен, буквально кожен для нього - рідний синок або рідна дочечка. I національність дитини ні на що не впливала! Серед нас, українців, був і татарин, і кореянка, і євреї, і росіяни.

Я попервах усе тікала додомку... Кілька разів утікала! Тоді з дитбудинку прийдуть - заберуть мене, повернуть назад. А потім директор і питається мене у своєму кабінеті, сам на сам:

- Галю, скажи мені: ну чого ти тікаєш? Хіба тобі тут так погано?

- Не знаю... Ні... Непогано. Та я... Я до мами... своєї... хочу!

- Може, тебе тут хтось зобиджає? Так ти скажи - я накажу!

- Ні... просто... до мами...

При такому турботливому ставленні втікати я скоро перестала. А невдовзі й посміливішала у великому колективі. Загалом-то я була дуже сором'язливою. А так хотіла співати! Сама. Голос був... Та соромилася страшенно. І відважувалася співати лише у хорі. Правда, потім почала читати зі сцени вірші. Байки, зокрема. Тепер розумію, що підсвідомо брала приклад з нашого нового батька - Михайла Андрійовича. Він-бо завжди виглядав упевненою особистістю, вольовою людиною, що здатен був сам приймати не просто важливі - незвичайні рішення. Уявити тільки: він навіть не відправляв до міських гуртожитків тих зі своїх випускників, котрі вступали до Охтирського мед-, педучилища. По три роки, попри всі правила (а це яка була епоха, страшно подумати!) ще утримував їх у дитбудинку! Годував і одягав, - усе, як положено. Бо були ми для нього всі, до єдиного, не просто державні, «казьонні» вихованці, а такі любі, такі дорогі серцю синочки й дочечки. Справді рідні!».

Доля не відміряла М. А. Гордієнкові довгих літ. Коли він відійшов у вічність, багато його вихованців зібралося провести його в останню путь як найріднішу людину. Педагог А. М. Павленко (Павленко, 1998) згадувала, що «на похороні Михайла Андрійовича Гордієнка дівчинка-сирота 3 блокадного Ленінграду Віта Зекрета, ридаючи, приказувала: »Прощавай, наш Батьку! Ми тебе ніколи не забудемо!», і ці слова міг з нею повторити кожен.

Хто ж нині реально - через десятиліття! - відкрив нам постать Педагога Гордієнка? 3 чиєї легкої руки впало 3 неї покривало забуття?Це Галина Хілько, у заміжжі - Гапонова, вихованка Михайла Андрійовича Гордієнка. Її батько, 
рядовий боєць, був серед тих, хто в 1943 році звільняв Охтирку, а невдовзі загинув на території Полтавщини. Відносно недавно (навесні 2017 року) саме Галина Петрівна Гапонова - вже у віці 82-х років! - стала першим і єдиним ініціатором встановлення меморіальної дошки на одному з будинків на вулиці Сумській (колишня імені Фрунзе), де знаходився цей заклад для сиріт, а також ініціатором написання та спонсором видання книги про нього «Дочки і синочки, або Життя за Піфагором: «Бережіть сльози своїх дітей, аби вони могли плакати на Вашій могилі!» (Криницька, 2019). Через усю цю книгу, хоча й підспудно, але яскраво-червоною ниткою проходить одна 3 головних ідей видання: дуже багато у будь-якій справі залежить від однієї-однісінької людини! У цьому випадку залежало від талановитого, самовідданого педагога Михайла Андрійовича Гордієнка.

Охтирський міський краєзнавчий музей та особисто його директор Людмила Міщенко і науковий співробітник Олена Бойко нині приділяють чимало уваги постаті унікального місцевого педагога Михайла Гордієнка. 3 ініціативи Г. П. Гапонової та за ії допомогою саме вони створили спеціальну вітрину, у якій зібрано фото, документальна повість-есе, документальні матеріали про його життя та діяльність, про дитбудинок, котрий він очолював, його вихованців.

Висновки. Для сьогоднішніх практичних педагогів, котрі працюють 3 дітьми-сиротами та недавніми безпритульними, трудяться у нелегких, зовсім нових соціально-економічних умовах, буде відмітною професійною знахідкою знайомство із Михайлом Гордієнком - заново відкритою педагогічною постаттю. Відкритою не для поверхового знайомства, а перш за все - для використання його особистих творчих здобутків, великого досвіду.

Нині пошук тих, хто може поділитися спогадами про Педагога, про його виховний досвід, триває.

\section{Список використаних джерел}

Кривич, О. (2016). Організаційно-методичні засади діяльності Охтирського дитячого містечка імені М. О. Скрипника як виховного закладу інноваційного типу (20-ті роки ХХ століття). Витоки педагогічної майстерності, 17, 96-102.

Криницька Л. (2019). Дочки і синочки, або Життя за Піфагором: «Бережіть сльози своїх дітей, аби вони могли плакати на Вамій могилі!». (Історія дитячого будинку - історія самої Охтирки): документальна повість-есе. Харків: Факт.

Павленко, А. (1998). Нас водила молодість... Прапор перемоги: Охтирська міськрайонна газета, 9 трав.

Скільки дітей в Україні є сиротами: статистика усиновлення. (2019). Рyх реформ, 4 верес. Взято 3 https://reformation.r500.ua/analytics/skilky-ditei-v-ukraini-ie-syrotamy-statystyka-usynovlennia/.

Штань, О. О. (2017). Охтирський Свято-Троїцький чоловічий монастир як осередок дитячого виховання у $1920-1930$ рр. Педагогіка в системі гуманітарного знання. III Міжнар. наук.-практ. конф. (с. 24-27). Херсон: Гельветика. Взято 3 http://molodyvcheny.in.ua/files/conf/ped/24sept2017/7.pdf.

\section{References}

Kryvych, O. (2016). Orhanizatsiino-metodychni zasady diialnosti Okhtyrskoho dytiachoho mistechka imeni M. O. Skrypnyka yak vykhovnoho zakladu innovatsiinoho typu (20-ti roky XX stolittia) [Organizational and methodological foundations of the activity of Okhtyr Children's Village named after MA Skrypnyk as an educational institution of innovative type (20-ies of the XX century)]. Vytoky pedahohichnoi maisternosti [Origins of pedagogical skill], 17, 96-102 [in Ukrainian].

Krynytska L. (2019). Dochky i synochky, abo Zhyttia za Pifahorom: «Berezhit slozy svoikh ditei, aby vony mohly plakaty na Vashii mohyli!». (Istoriia dytiachoho budynku - istoriia samoi Okhtyrky) [Daughters and sons, or Life after Pythagoras: "Keep the tears of your children that they may weep on your grave!" (The story of the orphanage is the story of Okhtyrka itself)]: dokumentalna povist-ese. Kharkiv: Fakt [in Ukrainian].

Pavlenko, A. (1998). Nas vodyla molodist... [We were led by youth ...]. Prapor peremohy [Victory flag]: Okhtyrska miskraionna hazeta, 9 trav. [in Ukrainian].

Shtan, O. O. (2017). Okhtyrskyi Sviato-Troitskyi cholovichyi monastyr yak oseredok dytiachoho vykhovannia u $1920-1930$ rr. [Okhtyr Holy Trinity Monastery as the center of children's education in 1920-1930.]. Pedahohika v systemi humanitarnoho znannia [Pedagogy in the system of humanitarian knowledge]. III Mizhnar. nauk.-prakt. konf. (pp. 2427). Kherson: Helvetyka. Retrieved from http://molodyvcheny.in.ua/files/conf/ped/24sept2017/7.pdf [in Ukrainian].

Skilky ditei v Ukraini ye syrotamy: statystyka usynovlennia [How many children in Ukraine are orphans: adoption statistics]. (2019). Rukh reform [The reform movement], 4 veres. Retrieved from https://reformation.r500.ua/analytics/skilky-ditei-vukraini-ie-syrotamy-statystyka-usynovlennia/ [in Ukrainian].

\section{PYVOVAR N., KRYVONOS Y.}

Poltava V. G. Korolenko national pedagogical University, Ukraine

\section{MYKHAILO GORDIENKO - A RE-OPENED FIGURE IN NATIONAL PEDAGOGY}

The article is written in the context of the current search, study and publication of the best pedagogical experience of little-known teachers, masters of pedagogical work, which would serve to solve similar problems of upbringing orphans, but 
in completely new socio-economic conditions. Dedicated to the pedagogical heritage of Mykhailo Gordienko - principal of the Okhtyr Special Orphanage №1 (Ukraine).

The aim of the article is to investigate the nature and peculiarities of M. A. Gordienko's work from pedagogical positions, with a view to using elements of his experience in working with orphans in modern conditions.

There are no enough informative and analytical publications about M. Gordienko, but his former employees and students, local historians of Okhtyrka are doing a lot to preserve the pedagogical heritage of this talented person. The authors of the article insist that it can be very useful to work with orphans in today's environment.

Keywords: pedagogical inheritance; Mykhailo Gordienko; orphans; homelessness; special orphanage; management; labor education

Стаття надійшла до редакції 27.09.2019 р.

Удк 378.011.3-051:796-047.37

DOI: https://doi.org/10.33989/2075-146x.2019.24.194869

\title{
ОЛЕКСАНДР ПОЛОНСЬКИЙ
}

ORCID ID 0000-0001-6697-3241

Полтавський національний педагогічний університет імені В. Г. Короленка

\section{СТРУКТУРА ОРГАНІЗАЦІЇ НАУКОВО-ДОСЛІДНОЇ РОБОТИ НАЦІОНАЛЬНОЇ АКАДЕМІЇ НАЦІОНАЛЬНОЇ ГВАРДІЇ УКРАЇНИ}

\begin{abstract}
У статті визначено роль та місце науково-дослідницької діяльності у системі професійної підготовки майбутнього офіцера національної гвардії, яка є основою формування науково-дослідної компетентності фахівця. Визначено стратегічні завдання підготовки фахівців у Національній академії Національної гвардії України. Встановлено, що науково-дослідна робота академії здійснюється за напрямками п'яти факультетів: оперативно-тактичний; командно - штабний, факультет логістики, гууманітарний факультет та київський факультет. На основі комплексного аналізу встановлено, що Науково-дослідний центр службово-бойової діяльності Акдемії призначений для наукового забезпечення подальшого розвитку НГУ. Визначено завдання і напрямки діяльності науководослідних лабораторій академії. Досліджено структуру та склад науково-технічної ради, визначено функції та напрямки діяльності її секцій: секція військових наук; секція технічних наук; секція гуманітарних наук; секція економічних наук.
\end{abstract}

Ключові слова: майбутній офіцер Національної гвардії; науково-дослідна діяльність; науководослідна компетентність; науково-дослідний центр; науково-дослідні лабораторії

Постановка проблеми. Трансформація соціально-економічних та політичних умов на сучасному етапі розвитку українського суспільства потребує прогресивних інновацій у системі професійної підготовки. В умовах європейської інтеграції, тотальної інформатизації та технологізації освіти зростають вимоги до професійної підготовки майбутніх офіцерів Національної гвардії України. Для майбутніх офіцерів актуальними $є$ такі якості особистості, як готовність до постійної самоосвіти, креативність, здатність здійснювати пошукову діяльність, отримувати нові знання, бачити перспективи власної самоосвітньої траєкторії і планувати стратегію іiі розвитку (Бец, 2011).

Завдання, які сьогодні виконує Національна гвардія України вимагає від Академії підготовки сучасних та кваліфікованих офіцерів. Бойовий досвід, кращий досвід країн НАТО та країн міжнародної асоціації FIEP (фієп) активно впроваджується в навчальний процес і вимагає від викладачів та курсантів ефективної взаємодії. Все це задля досягнення головної мети - мирного та безпечного майбутнього кожного громадянина своєї країни.

Особливу роль у процесі фахової підготовки майбутнього офіцера Національної гвардії відводиться науководослідній діяльності, яка є основою формування науково-дослідної компетентності фахівця. Науково-дослідна робота $є$ провідним видом наукової і науково-технічної діяльності, яка проводиться у Національній академії Національної гвардії України під керівництвом науково-педагогічних (наукових) працівників та спрямована на підвищення якості підготовки офіцерських кадрів, розвитку у них творчого мислення, навичок проведення самостійних наукових досліджень та організації наукової роботи, здатність осмислювати практичні проблеми та ефективні шляхи їх вирішення (Тробюк, 2017).

Наукова діяльність здійснюється відповідно до Конституції України, Законів України «Про наукову і науковотехнічну діяльність», «Про пріоритетні напрями розвитку науки і техніки», «Про наукову і науково-технічну експертизу», інших нормативно-правових актів України, що стосуються наукової і науково-технічної діяльності, наказів Міністра внутрішніх справ України, Командувача Національної гвардії України, Міністерства освіти та науки України.

Аналіз останніх досліджень $\boldsymbol{i}$ публікацій. Аналітико-пошукова робота з проблеми, яка розглядається, дозволила встановити, що сьогодні існує низка досліджень, у яких розглядається проблематика науково-дослідної діяльності, це, насамперед, праці І. Беца, В. Бордовського, Л. Квіткіна, М. Князяна, О. Торічного, В. Шейка, 